\title{
Carbonaceous particles reveal that Late Holocene dust causes the dark region in the western ablation zone of the Greenland ice sheet
}

\author{
I.G.M. WIENTJES, ${ }^{1}$ R.S.W. VAN DE WAL, ${ }^{1}$ M. SCHWIKOWSKI, ${ }^{2}$ A. ZAPF, ${ }^{2}$ \\ S. FAHRNI, ${ }^{3}$ L. WACKER ${ }^{3}$ \\ ${ }^{1}$ Institute for Marine and Atmospheric Research Utrecht (IMAU), Utrecht University, Utrecht, The Netherlands \\ E-mail: r.s.w.vandewal@uu.nl \\ ${ }^{2}$ Paul Scherrer Institut, Villigen, Switzerland \\ ${ }^{3}$ Institute for Particle Physics, ETH Zürich, Zürich, Switzerland
}

\begin{abstract}
A dark region in the western ablation zone of the Greenland ice sheet is caused by outcropping ice layers that contain more dust than the surrounding brighter ice. These higher amounts of dust were deposited in the accumulation zone of the ice sheet and travelled with the ice to the ablation zone. To deduce the period and the causes of this higher dust deposition, carbonaceous particles in ice samples from the dark region and from brighter reference ice were analysed and used for dating. Samples including ice from directly below the surface contain high amounts of modern organic carbon, probably from microorganisms on the ice surface. Deeper samples reveal low amounts of carbonaceous particles, which are originally deposited in the accumulation zone. The amount of outcropping carbonaceous particles in the dark region seems significantly higher than in the reference ice. One of the samples that contained material initially deposited in the accumulation zone was dated and revealed Late Holocene ages, coinciding with a period of enhanced eolian activity in the nearby tundra. Therefore, variable eolian activity during the Holocene effected dust fluxes towards the ice and hence leads to albedo variations in the present ablation zone of the ice sheet.
\end{abstract}

\section{INTRODUCTION}

Satellite images reveal a region in the western part of the Greenland ice sheet that is darker than the surrounding ice (e.g. Oerlemans and Vugts, 1993; Van de Wal and Oerlemans, 1994) (Fig. 1). Previous studies suggested that accumulation of meltwater at the ice surface caused this darkening, as a result of slow internal drainage of water due to cold ice and low supraglacial drainage caused by a low surface slope (e.g. Knap and Oerlemans, 1996; Greuell, 2000). However, as the dark region compared with the brighter reference ice shows a spectral pattern typical of ice containing more debris, higher concentrations of dust in the ice are a more plausible cause for the surface darkening (Wientjes and Oerlemans, 2010). As the dark region is found every summer in the same position at some distance from the margin, it seems not only to be caused by recent windblown material from the tundra or by recent dry and wet deposition. Another possible mechanism via which the dust could reach the dark region is glacial transport, after settling higher on the ice sheet in the accumulation zone (Fig. 2). Wavy patterns in the dark region observed on Advanced Spaceborne Thermal Emission and Reflection Radiometer (ASTER) images confirm the outcropping of stratified ice layers in the dark region (Wientjes and Oerlemans, 2010). Wientjes and others (2011) investigated surface dust from the dark region as well as from the reference ice and observed that it mainly has the same composition, mostly mineral dust and microbes. They also found strong indications that this dust has a local origin, probably the West Greenland tundra.

Owing to the flow pattern in an ice sheet, a horizontal surface ice profile in the ablation zone perpendicular to the margin corresponds with a vertical ice core in the accumulation zone and therefore represents a timeline (e.g. Reeh and others, 1987). This implies that the closer to the margin, the older the ice is. For this reason we assume that the sharp transition between the dark region and the brighter ice represents an isochrone and that higher amounts of dust originate from a period when more material settled on the ice (e.g. colder periods when more dust reached the ice sheet due to drier and windier conditions). However, it is not very likely that the dark region originates from a glacial, because the dark region is situated several kilometres to tens of kilometres from the margin. This is supported by observations near Paakitsoq, where Pleistocene ice was observed only very close to the margin (Reeh and others, 2002; Petrenko and others, 2006).

In order to find out in which period the dust was deposited on the ice sheet, ${ }^{14} \mathrm{C}$ dating of water-insoluble carbonaceous particles in the ice seems a suitable method (e.g. Jenk and others, 2006, 2007). Promising results have been obtained even for low carbon concentrations (5$100 \mu \mathrm{g} \mathrm{C)} \mathrm{(Jenk} \mathrm{and} \mathrm{others,} \mathrm{2009),} \mathrm{although} \mathrm{Sigl} \mathrm{and} \mathrm{others}$ (2009) claim that the application of this method is of limited use for polar ice due to the very low concentrations of carbonaceous particles. However, as the dark region contains high amounts of dust, we expected that high enough amounts of carbonaceous particles have been deposited as well to enable application of the ${ }^{14} \mathrm{C}$ dating technique. Part of the methodology involves separating the total carbonaceous matter in organic carbon (OC) and elemental carbon (EC). The OC fraction contains low to medium molecular weight compounds, which are emitted directly to the atmosphere or generated from gaseous precursors as secondary organic aerosol (SOA). Since the combustion of fossils fuels was low in pre-industrial times, 


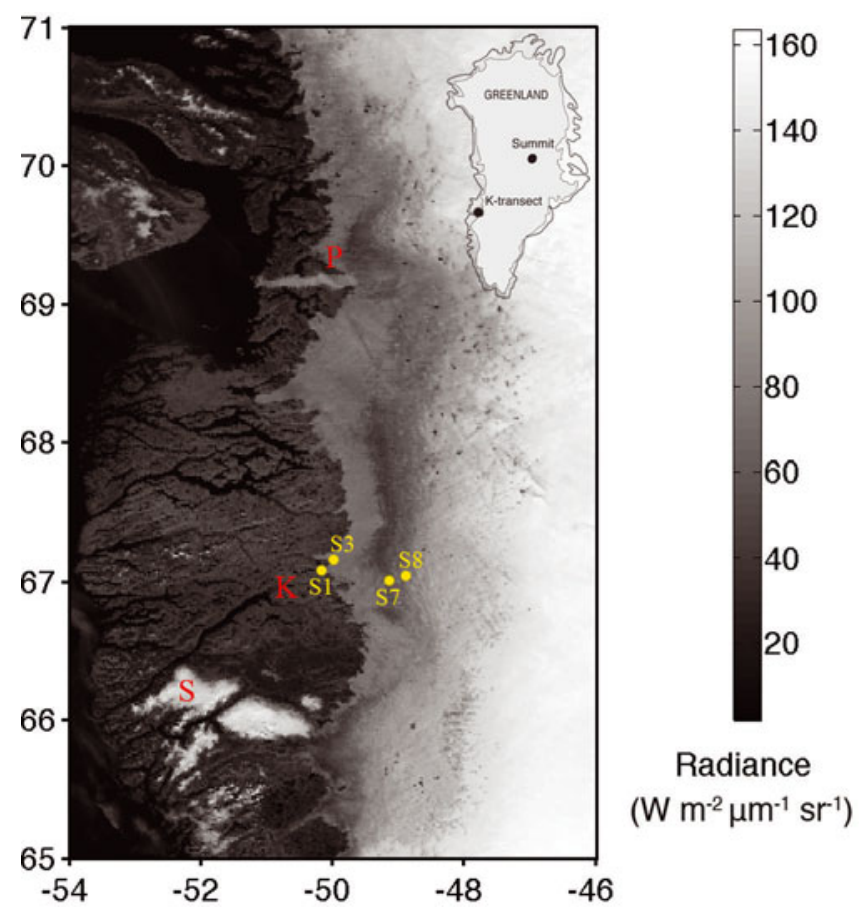

Fig. 1. Moderate Resolution Imaging Spectroradiometer (MODIS) image from 9 August 2007, band 2 (841-876 nm), showing the dark region in the melt zone of the Greenland ice sheet (adapted from Wientjes and Oerlemans, 2010). S: Sukkertoppen Iskappe; K: Kangerlussuaq; P: Paakitsoq area. S1 and S3 represent sampling locations from the reference ice, and S7 and S8 sampling locations from the dark region. Geographical coordinates are shown along the axes.

OC was predominantly emitted from vegetation (Jenk and others, 2006), implying that this biogenic carbon has the ${ }^{14} \mathrm{C} /{ }^{12} \mathrm{C}$ ratio of the living biosphere at the time of photosynthesis. The EC fraction consists of highly polymerized hydrocarbons and is separated from OC by its thermal properties. In principle it represents the same fractions as black carbon (BC). It is formed through incomplete combustion processes from natural biomass burning or more recently from anthropogenic sources. Because the source material for EC could be formed some time before burning, it can lead to radiocarbon ages that are older than their time of emission into the atmosphere (referred to as the inbuilt age). EC could therefore have a different ${ }^{14} \mathrm{C} /{ }^{12} \mathrm{C}$ ratio than the ${ }^{14} \mathrm{C} /{ }^{12} \mathrm{C}$ ratio of $\mathrm{OC}$ at the time of combustion. These different ages can also occur for material on the Greenland ice sheet. For example, if the carbonaceous material on the ice originates from wood fires (e.g. Chylek and others, 1995), EC can have slightly older ages than OC. To account for these types of effects, we distinguish between $\mathrm{OC}$ and EC and both fractions were treated separately.

The main goals of this paper are to show evidence for the presence of old dust in the dark region, to reveal the period (Late Holocene) in which this old dust settled on the ice sheet and to discuss if high concentrations of carbonaceous material might contribute to the presence of the dark region. We describe the OC and EC concentrations from ice collected in the dark region as well as from reference ice outside the dark region and compare them with values in the literature. In contrast to our expectation, most samples have low carbon concentrations. We present the radiocarbon ages as far as they could be determined given these low carbon concentrations. Finally, we present conclusions from both the concentrations and the dates.

\section{ICE SAMPLES}

The ice cores from the dark region were sampled with a simple Polar Ice Coring Office (PICO) drill during two different field campaigns (for the exact locations and sample characteristics, see Fig. 1; Table 1). In April 2008 three ice cores were drilled, consisting of different pieces. The longest ice core of $\sim 2 \mathrm{~m}$ was retrieved at Site 7 . This core was divided into two samples, S7-1 and S7-2. Two smaller ice cores of $\sim 0.8 \mathrm{~m}$ were drilled at Site 8 . These were treated as separate samples S8-1 and S8-2. The upper part of sample S8-2, a piece of $\sim 15 \mathrm{~cm}$, contained cracks and holes (Fig. 3) and thus was not used for further analyses as such holes were in contact with the present atmosphere, potentially leading to a ${ }^{14} \mathrm{C}$ age not representative of the ice sample. In September 2009 we drilled three small cores of $\sim 0.2-0.3 \mathrm{~m}$ at Site 8, which were treated as one sample (S8-3). In addition we drilled six cores each $\sim 0.25-0.35 \mathrm{~m}$ and one of $\sim 0.6 \mathrm{~m}$ at Site 7 . The cores were drilled several metres apart from each other. Although these cores appeared normal in the field, during sample preparation we discovered very small melt holes in the ice which contained dark material at the bottom (Fig. 3). These holes were most likely formed by surface material that was melted into the ice, a phenomenon

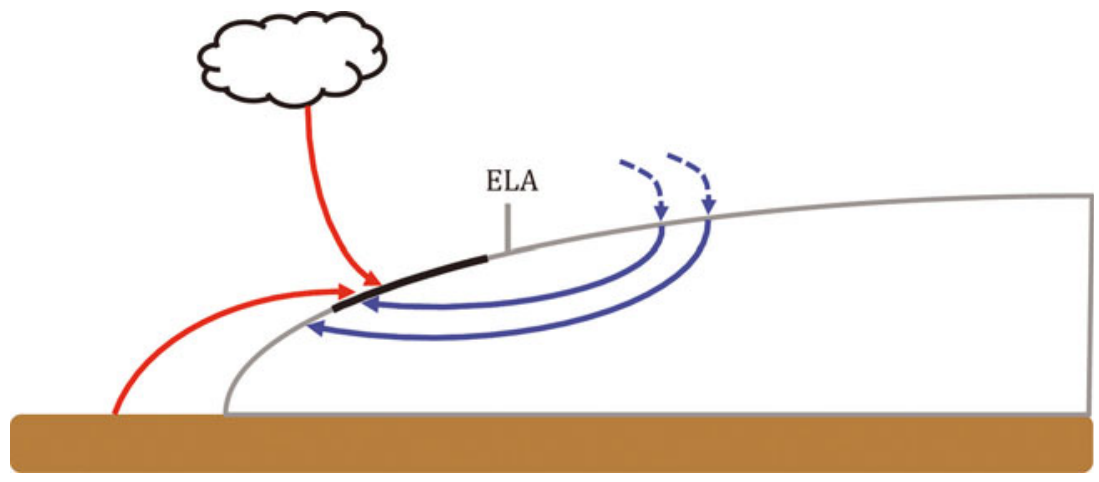

Fig. 2. Schematic overview of possible mechanisms by which dust can reach the ablation zone of an ice sheet (modified after Wientjes and others, 2011). The red arrows indicate recent dry or wet deposition from the atmosphere and recent wind-blown material from the nearby tundra, whereas the blue arrows represent particle trajectories in the ice. In both cases, the material can originally have the same source, but the age will be different. ELA indicates the equilibrium-line altitude, and the black line at the surface indicates the dark region. 
Table 1. Overview of the sample characteristics. Numbers of cores and final pieces as well as the net weight forming a sample that was used for the analyses are given

\begin{tabular}{|c|c|c|c|c|c|c|c|}
\hline \multirow[t]{2}{*}{ Sample } & \multirow[t]{2}{*}{ Coordinates } & Height & \multirow[t]{2}{*}{$\begin{array}{c}\text { Number of } \\
\text { cores }\end{array}$} & \multirow[t]{2}{*}{$\begin{array}{c}\text { Number of } \\
\text { pieces }\end{array}$} & \multirow{2}{*}{$\begin{array}{c}\text { Average length } \\
\text { of pieces } \\
\text { cm }\end{array}$} & \multirow{2}{*}{$\begin{array}{c}\text { Net weight } \\
\text { g }\end{array}$} & \multirow[t]{2}{*}{$\begin{array}{l}\text { Depth below } \\
\text { surface }\end{array}$} \\
\hline & & ma.s.I & & & & & \\
\hline S8-1 & $67^{\circ} 00^{\prime} 16^{\prime \prime} \mathrm{N}, 48^{\circ} 52^{\prime} 02^{\prime \prime} \mathrm{W}$ & 1260 & 1 & 5 & $16.8 \pm 6.8$ & 1732 & 0 \\
\hline S8-2 & $67^{\circ} 00^{\prime} 16^{\prime \prime} \mathrm{N}, 48^{\circ} 52^{\prime} 02^{\prime \prime} \mathrm{W}$ & & 1 & 4 & $16.9 \pm 5.1$ & 1590 & $\sim 15 \mathrm{~cm}$ \\
\hline S8-3 & $67^{\circ} 00^{\prime} 16^{\prime \prime} \mathrm{N}, 48^{\circ} 52^{\prime} 02^{\prime \prime} \mathrm{W}$ & & 3 & 4 & $17.3 \pm 8.4$ & 1045 & 0 \\
\hline S7-1 & $66^{\circ} 59^{\prime} 31^{\prime \prime} \mathrm{N}, 49^{\circ} 08^{\prime} 19^{\prime \prime} \mathrm{W}$ & 1110 & $1 / 2$ & 4 & $18.0 \pm 9.3$ & 1512 & 0 \\
\hline S7-2 & $66^{\circ} 59^{\prime} 31^{\prime \prime} \mathrm{N}, 49^{\circ} 08^{\prime} 19^{\prime \prime} \mathrm{W}$ & & $1 / 2$ & 9 & $9.9 \pm 1.7$ & 1638 & $\sim 90 \mathrm{~cm}$ \\
\hline S7-3 & $66^{\circ} 59^{\prime} 31^{\prime \prime} \mathrm{N}, 49^{\circ} 08^{\prime} 19^{\prime \prime} \mathrm{W}$ & & 7 & 13 & $10.7 \pm 3.7$ & 2812 & $5-20 \mathrm{~cm}$ \\
\hline $\mathrm{S} 1-1$ (ref) & $67^{\circ} 05^{\prime} 15^{\prime \prime} \mathrm{N}, 50^{\circ} 14^{\prime} 09^{\prime \prime} \mathrm{W}$ & 250 & part & 6 & $24.2 \pm 5.0$ & 2046 & Several metres \\
\hline $\mathrm{S} 1-2$ (ref) & $67^{\circ} 05^{\prime} 15^{\prime \prime} \mathrm{N}, 50^{\circ} 14^{\prime} 09^{\prime \prime} \mathrm{W}$ & & & & & 1940 & \\
\hline S3-1 (ref) & $67^{\circ} 09^{\prime} 16^{\prime \prime} \mathrm{N}, 49^{\circ} 58^{\prime} 41^{\prime \prime} \mathrm{W}$ & 650 & part & 9 & $19.3 \pm 7.8$ & 1913 & Several metres \\
\hline S3-2 (ref) & $67^{\circ} 09^{\prime} 16^{\prime \prime} \mathrm{N}, 49^{\circ} 58^{\prime} 41^{\prime \prime} \mathrm{W}$ & & & & & 2241 & \\
\hline
\end{tabular}

known as cryoconite holes. They have diameters of a few millimetres and depths between 5 and $>20 \mathrm{~cm}$ for the different cores. The holes have the same depth (within $1 \mathrm{~cm}$ ) for each single core. This indicates that the surface debris melts in the ice until a certain depth is reached. Such an equilibrium depth for cryoconite holes has been observed before (e.g. Gribbon, 1979). Because the holes seemed to be in contact with the present atmosphere and because the material at the bottom was likely to be modern, they could influence the radiocarbon dating of the dust. We therefore decided not to use the pieces affected by the cryoconite holes and cut these pieces off directly below the melt holes. The remaining parts were treated as one large sample, S7-3. Hence, samples S8-1, S8-3 and S7-1 contained ice from directly below the surface, in contrast to the other three samples (S7-2, S7-3 and S8-2).

Four reference samples were taken from several pieces of two deeper ice cores (S1 and S3) that were drilled in 1995 in brighter ice located closer to the ice-sheet margin than the dark region. Samples S1-1 and S1-2 were obtained from one core at Site 1 and samples S3-1 and S3-2 from one core at Site 3. These samples contained ice from a depth of several metres.

\section{METHOD}

The ice cores were prepared following the method described by Jenk and others (2007). During preparation the outer parts of the ice cores (including the upper centimetres of the surface) were removed and several cracks in the cores were cut out to avoid possible contamination. In the next step they were rinsed with ultrapure water (Milli-Q, $18 \mathrm{M} \Omega \mathrm{cm}$ ). After melt, the samples were filtered using freshly preheated quartz fibre filters (Pallflex Tissuquartz, 2500QAO-UP). Afterwards, the filters were acidified with $50 \mu \mathrm{L}$ of $0.2 \mathrm{M} \mathrm{HCl}$ to remove carbonates. Samples were prepared in laminar flow boxes and all materials used were made of quartz, glass, stainless steel or Teflon.
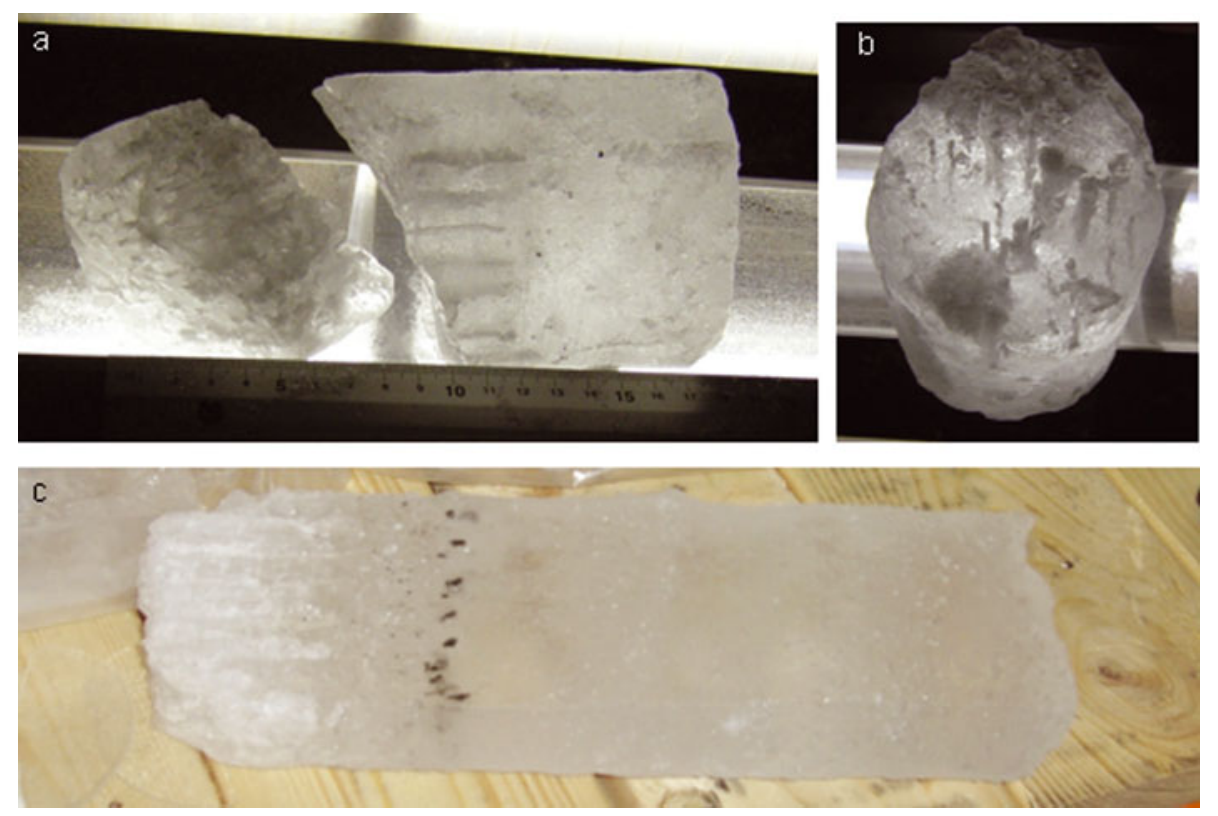

Fig. 3. (a, b) The uppermost piece of sample S8-2, with holes and cracks in the ice. (c) One of the cores at S7-3, with melt holes and debris at $\sim 10 \mathrm{~cm}$ depth. 
Table 2. Particulate OC and EC concentrations in the ice samples

\begin{tabular}{lrc}
\hline Sample & \multicolumn{1}{c}{ OC } \\
& $\mu \mathrm{g} \mathrm{kg}^{-1}$ & $\begin{array}{c}\text { EC } \\
\mu \mathrm{kg}^{-1}\end{array}$ \\
\hline S8-1* & $75.94 \pm 1.69$ & $4.21 \pm 0.12$ \\
S8-2 & $3.94 \pm 0.13$ & $3.05 \pm 0.13$ \\
S8-3* & $98.18 \pm 2.25$ & $7.85 \pm 0.20$ \\
S7-1* & $76.53 \pm 1.74$ & $2.92 \pm 0.07$ \\
S7-2 & $1.28 \pm 0.06$ & $1.77 \pm 0.06$ \\
S7-3 (ref) & $1.53 \pm 0.07$ & $1.32 \pm 0.07$ \\
S1-1 (ref & $15.76 \pm 0.34$ & $1.99 \pm 0.05$ \\
S1-2 (ref) & $19.44 \pm 0.42$ & $0.65 \pm 0.05$ \\
S3-1 (ref) & $0.56 \pm 0.05$ & $0.46 \pm 0.05$ \\
S3-2 (ref) & $1.01 \pm 0.04$ & $0.58 \pm 0.04$ \\
& & \\
\hline
\end{tabular}

*Samples containing ice from directly below the surface.

For the separation of OC and EC, the THEODORE (twostep heating system for the EC/OC determination of radiocarbon in the environment) system was used, as described by Szidat and others (2004). Hereby, the samples were combusted under a stream of oxygen at $340^{\circ} \mathrm{C}$ for $10 \mathrm{~min}$ (for OC) and at $650^{\circ} \mathrm{C}$ for $12 \mathrm{~min}$ (for EC). The $\mathrm{CO}_{2}$ formed during combustion was cryogenically trapped and sealed in glass ampoules. OC and EC concentrations were determined by manometry.

The final ${ }^{14} \mathrm{C}$ analyses were performed using a $200 \mathrm{kV}$ compact radiocarbon accelerator mass spectrometry (AMS) system (Synal and others, 2007) with a gas ion source (Ruff and others, 2007) at ETH Zürich, Switzerland. This system, the Mini Radiocarbon Dating System (MICADAS), allows for direct measurement of the gaseous samples. The results were expressed as $f_{M}$ (fraction of modern carbon), which is 1 for modern carbon and 0 for fossil carbon. To determine possible contamination during the different steps of the sample processing, procedural blanks were analysed. Therefore artificial ice blocks of frozen ultrapure water were treated and measured in the same way as real ice samples. For details of the procedural blank used in this study see Sigl and others (2009). The correction finally applied to the AMS results due to this procedural blank is

$$
f_{\mathrm{M} \text { correct }}=\frac{m_{\mathrm{C}} \cdot f_{\mathrm{M} \text { initial }}-m_{\text {proc blk }} \cdot f_{\mathrm{M} \text { proc blk }}}{\left(m_{\mathrm{C}}-m_{\text {proc blk }}\right)}
$$

where $f_{M}$ denotes the ${ }^{14} \mathrm{C} /{ }^{12} \mathrm{C}$ ratio observed relative to the ratio of the year $1950, f_{M}$ initial the value before correction for the procedural blank and $m_{\mathrm{C}}$ the carbon mass separated for AMS analysis.

The obtained ${ }^{14} \mathrm{C}$ ages were calibrated using the OxCalv4.1.7 software (2010 update of Bronk Ramsey, 2001) with the IntCal09 calibration curve (Reimer and others, 2009), with the exception of over-modern values $\left(f_{M}>1\right)$ which were calibrated using the Bomb04NH1curve (Hua and Barbetti, 2004).

\section{CARBON CONCENTRATIONS} $O C$ and EC measurements

The OC and EC concentrations of the different samples are shown in Table 2. Samples S8-1, S8-3, S7-1, S1-1 and S1-2 have high $\mathrm{OC}$ concentrations relative to the other samples. The samples from the dark region with high OC concentrations, S8-1, S8-3 and S7-1, contain ice from directly below the surface. The other samples from the dark region, S8-2, S7-2 and S7-3, have much lower OC concentrations, indicating that the high $\mathrm{OC}$ concentrations are not part of the outcropping ice but originate from the surface. Microorganisms that live on the ice have likely formed the high amounts of OC (e.g. Stibal and others, 2010). This organic debris must have penetrated into the ice by melting from the surface, although the parts of the samples with visible melt holes were removed. The two samples from Site 7 without high OC concentrations, S7-2 and S7-3, show OC concentrations that are similar to each other, although S7-3 consists of different smaller ice cores cut off directly below the visible melt holes, whereas S7-2 is the lowermost part of one ice core at $\sim 90 \mathrm{~cm}$ depth. This indicates that below the melt holes, the concentration of $\mathrm{OC}$ is the same, independent of depth. The same applies to the concentrations of EC. Therefore, the carbonaceous particles below the melt holes seem to be all outcropping and hence transported through the ice sheet.

Both reference samples that contain high OC concentrations are from Site 1. The filtering of these two samples indicated fine mud-like material in the meltwater. In addition, these samples were taken from several metres below the surface but contain small stone-like particles. This indicates that they probably contain moraine or bedrock entrained debris, which is plausible as Site 1 is located very near the ice margin on an outlet glacier. Because the ice sheet was smaller in the past (e.g. Van Tatenhove and others, 1996), it is reasonable to assume that the bedrock close to the present margin was covered with vegetation and therefore still contains organic material. Basally entrained material in these samples explains why the OC concentration is significantly higher than for the other samples taken at some depth below the surface.

The EC concentrations of the samples containing surface material are slightly higher relative to the other samples, probably due to the fact that together with the organic debris, EC particles from the surface melted into the ice. If we compare the different samples from the dark region without surface material, we observe that S8-2 has slightly higher OC and EC concentrations than S7-2 and S7-3. A possible explanation is that the outcropping ice at Site 8 has higher impurity concentrations; however, with only one sample from Site 8 at some depth, it is hard to draw firm conclusions.

In order to compare the amounts of carbonaceous particles in the outcropping ice between the dark region and the reference ice, we use the reference samples from Site 3 and samples S7-2, S7-3 and S8-2 from the dark region. The other samples seem to contain either material melted from the surface or basally entrained material. Figure 4 shows OC and EC concentrations averaged for the samples from Site 7 (S7-2 and S7-3) and Site 3 (S3-1 and S3-2). Although clearly based on a limited number of values, Figure 4 shows that the concentrations of glacially transported particles are higher in the dark region relative to the reference ice. We excluded S8-2 from this figure, as it was taken from another location and has different carbon concentrations. However, a figure including S8-2 shows quantitatively the same results.

In summary, we conclude that samples from directly below the surface contain high amounts of mostly OC, which seems to melt down from the surface. For the samples taken at some depth below the surface, the carbonaceous particles are transported through the ice sheet. Samples from Site 1 probably contain basally entrained material. If we 


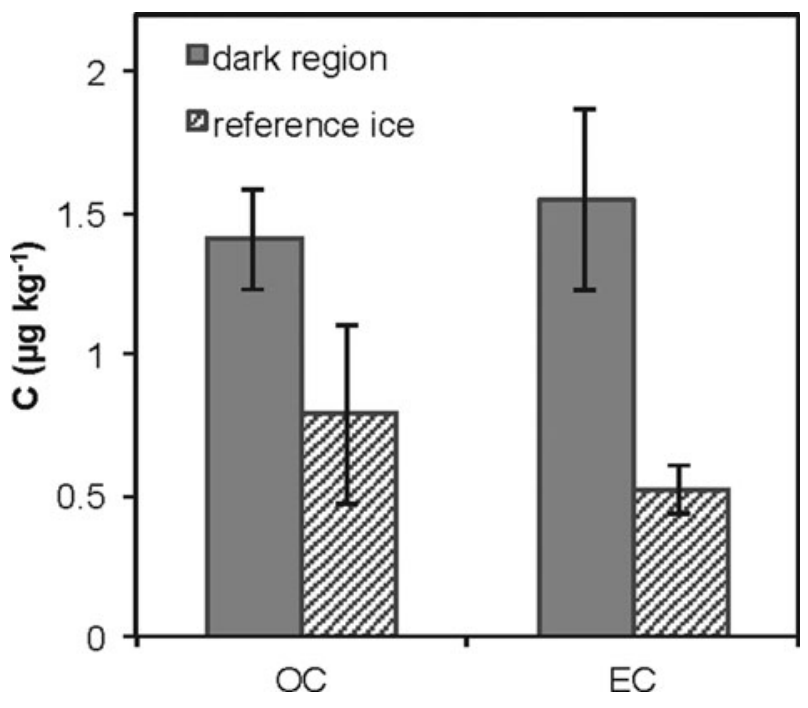

Fig. 4. Averaged OC and EC concentrations from two samples from the dark region (S7) and from two samples of the reference ice (S3). Error bars represent one standard deviation.

compare the samples from different locations, we observe that the concentration of glacially transported carbonaceous particles is larger in the dark region than in the reference ice.

\section{Comparing $\mathrm{OC}$ and EC concentrations with ice-core and snow samples}

Based on the hypothesis of high amounts of outcropping dust in the dark region (Wientjes and Oerlemans, 2010), we expected that the dark region also contains high amounts of carbonaceous particles. Although the measurements reveal that carbon concentrations in this region are significantly higher than in the surrounding reference ice, our initial assumption of high carbon concentrations turned out to be incorrect. To interpret these results in the context of general carbonaceous particle deposition on the Greenland ice sheet, we compare our findings with values from other locations reported in the literature.

The OC concentrations of our samples seem to be generally low compared with reported values from the Greenland ice sheet, except for the samples from directly below the surface (S8-1, S8-3, S7-1). Hagler and others (2007) presented water-insoluble particulate OC concentrations of $11.9 \mu \mathrm{g} \mathrm{kg}^{-1}$ in fresh snow and $3.1-8.4 \mu \mathrm{g} \mathrm{kg}^{-1}$ in snow from previous years at Summit. Differences in the analytical method and, more likely, a modern and anthropogenic character of this OC might contribute to the differences between these values and the concentration of our samples. Another possibility for these different concentrations could be post-depositional processes (Hagler and others, 2007). Jenk (2006) observed OC concentrations in the Paakitsoq area of $3.5 \mu \mathrm{g} \mathrm{kg}^{-1}$ for ice from $11.5 \mathrm{ka} \mathrm{BP}$ (Younger Dryas transition), $3.9 \mu \mathrm{g} \mathrm{kg}^{-1}$ for ice from $12.6 \mathrm{ka} \mathrm{BP}$ (Younger Dryas) and $4.7 \mu \mathrm{g} \mathrm{kg}^{-1}$ for ice from $14.7 \mathrm{ka} \mathrm{BP}$ (Older Dryas). These samples are all from glacial periods in which dryer and windier conditions accounted for high amounts of particles deposited on the ice sheet. This is confirmed by the fact that some of the samples were taken from visible dirt bands in the ice. Sigl and others (2009) presented OC concentrations from eight Greenland Ice Core Project (GRIP) ice-core samples from different time intervals which together cover most of the Holocene. Two of these samples have very high OC
Table 3. Elemental carbon concentrations from the Greenland ice sheet

\begin{tabular}{|c|c|c|c|}
\hline $\begin{array}{l}\text { EC } \\
\mu \mathrm{gkg}^{-1}\end{array}$ & Period & Location & Reference \\
\hline 4.1 & $12600 \mathrm{BP}$ & Paakitsoq & Jenk (2006) \\
\hline 5.2 & 14700 BР & Paakitsoq & Jenk (2006) \\
\hline 1.1 & $6000 \mathrm{BP}$ & Camp Century & Chylek and others (1987) \\
\hline 2.5 & 4000 вр & Camp Century & Chylek and others (1987) \\
\hline 2.1 and 2.6 & Recent snow & Camp Century & Chylek and others (1987) \\
\hline 1.7 & AD $320-330$ & GISP2 & Chylek and others (1995) \\
\hline 2.0 & Recent snow & GISP2 & Chylek and others (1995) \\
\hline $0.1-3.2$ & 100-3380 вР & Dye-3 & Chylek and others (1992) \\
\hline$<4.2$ & Recent snow & Dye-3 & Clarke and Noone (1985) \\
\hline $0.16-1.21$ & Recent snow & Summit & Hagler and others (2007) \\
\hline $4.2-30.1$ & Recent snow & Summit & Slater and others (2002) \\
\hline 1.7 & AD 1788-1850 & D4 site & $\begin{array}{l}\text { McConnell and others } \\
(2007)\end{array}$ \\
\hline 4.0 & AD 1851-1951 & D4 site & $\begin{array}{l}\text { McConnell and others } \\
(2007)\end{array}$ \\
\hline 2.3 & AD 1952-2002 & D4 site & $\begin{array}{l}\text { McConnell and others } \\
\text { (2007) }\end{array}$ \\
\hline
\end{tabular}

concentrations of 20 and $43 \mu \mathrm{g} \mathrm{kg}^{-1}$, whereas the other six have concentrations between 2.1 and $7.1 \mu^{g_{k g}} \mathrm{~g}^{-1}$ (average $3.5 \mathrm{\mu g} \mathrm{kg}^{-1}$ ). The OC concentration of sample S8-2 in this study has a comparable concentration of $3.9 \mu \mathrm{g} \mathrm{kg}^{-1}$. However, the OC concentrations of the other samples that were taken at some depth (S7-2, S7-3, S3-1 and S3-2) are clearly lower. Both our samples and the samples from Sigl and others (2009) are from the Holocene age and were analysed using the same method. Therefore we assume that the differences are due to the different locations on the ice sheet from which the respective ice originated, as GRIP is located at Summit (Fig. 1). As the exact processes leading to OC deposition on the Greenland ice sheet are not fully understood, explanations for these differences can only be speculative. Different sources (terrestrial vegetated areas as well as oceans), atmospheric transport routes and precipitation patterns and amounts possibly contributed to different deposition rates. Because particulate OC can be either emitted directly to the atmosphere or formed from gaseous precursors, varying chemical processes induced by different conditions might also play a role.

EC is assumed to be chemically inert, allowing for a better comparison. The EC concentrations in the samples in this study are generally in the same range as other values observed for the Greenland ice sheet (Table 3). In the Paakitsoq area, EC concentrations of 4.1 and $5.2 \mu \mathrm{g} \mathrm{kg}^{-1}$ were reported for the Younger and Older Dryas, respectively, using the same method as used here (Jenk, 2006). These concentrations are slightly higher than in the samples in this study, again probably because the samples from Jenk (2006), unlike the samples in this study, are from glacial periods with well-known high dust deposition on the Greenland ice sheet. Chylek and others (1987) presented concentrations of 1.1 and $2.5 \mu \mathrm{g} \mathrm{L}^{-1}$ for two ice samples with ages of $\sim 6$ and $\sim 4 \mathrm{ka}$, respectively, and 2.1 and $2.6 \mu \mathrm{g} \mathrm{L}^{-1}$ for recent snow from Camp Century. GISP2 ice-core samples (near Summit) were investigated by Chylek and others (1995), who reported a concentration of $2.1 \mathrm{\mu g} \mathrm{kg}^{-1}$ in samples from AD 320-330, a period with frequent extensive forest fires. This value reduces to $1.7 \mu \mathrm{g} \mathrm{kg}^{-1}$ when two large forest fires 
are left out of the analyses. The same authors presented a value of $2.0 \mu \mathrm{g} \mathrm{kg}^{-1}$ for recent snow, also at GISP2. Chylek and others (1992) reported an average of $1.53 \mu \mathrm{g} \mathrm{kg}^{-1}$ from 22 ice-core samples from Dye-3, varying from 0.1 to $3.2 \mu \mathrm{g} \mathrm{kg}^{-1}$, covering the period 3380-100 BP. Two slightly higher values of 4.3 and $8.5 \mu \mathrm{g} \mathrm{kg}^{-1}$ were observed near Dye-3 for samples from a snow pit collected by Clarke and Noone (1985), but investigation of seven other samples from this location revealed maximum EC concentrations between 1.2 and $6.2 \mu \mathrm{g} \mathrm{kg}^{-1}$. The averaged maximum value for all nine samples is $4.2 \mu \mathrm{g} \mathrm{kg}^{-1}$, but real EC concentrations are probably lower. Recent snow from Summit revealed concentrations of $0.16-1.21 \mu \mathrm{g} \mathrm{kg}^{-1}$ (Hagler and others, 2007). Higher concentrations of $4.2-30.1 \mu \mathrm{g} \mathrm{kg}^{-1}$ were observed for the same location by Slater and others (2002), but they explained that these higher values might be a result of the measurement method used. As the EC concentrations in our samples are not specifically high, the dark region does not seem to be caused by periods with high deposition of EC particles, as in extreme forest fires.

Anthropogenic sources could also account for higher amounts of EC deposition on the ice sheet, although the findings in the literature discussed above show little difference between concentrations from pre-industrial ice and modern snow. McConnell and others (2007) presented a continuous record of BC concentrations from 1788 to 2002 at D4, a location in the accumulation zone of the Greenland ice sheet $\left(71.4^{\circ} \mathrm{N}, 44.0^{\circ} \mathrm{W}\right)$. This record shows that $\mathrm{BC}$ concentrations, although highly variable in time, increased strongly after 1850 as a result of industrial emissions, followed by lower values after about 1950. McConnell and others (2007) reported an average pre-industrial BC concentration of $1.7 \mu \mathrm{g} \mathrm{kg}^{-1}$, an average concentration of $4.0 \mu \mathrm{g} \mathrm{kg}^{-1}$ for 1851-1951 and an average concentration of $2.3 \mu \mathrm{g} \mathrm{kg}^{-1}$ for 1952-2002 (Table 3). These findings are in general agreement with those in the literature discussed above. Investigations by McConnell and others (2007) at D5 $\left(68.5^{\circ} \mathrm{N}, 42.9^{\circ} \mathrm{W}\right)$, a location in the accumulation zone eastward of the dark region, show similar changes in BC. As the concentrations of glacially transported carbonaceous particles in the samples in this study agree most favourably with the pre-industrial values observed by McConnell and others (2007), we conclude that our samples are not anthropogenic. This is in agreement with the distance of tens of kilometres from Sites 7 and 8 to the equilibrium line, as material in the outcropping ice from these Site cannot have travelled such long distances through the ice sheet from the industrial revolution until now.

Based on these comparisons we conclude that the concentrations of outcropping OC in our samples are relatively low compared with findings in the literature, for different reasons, whereas the outcropping EC concentrations agree well with other values from the Greenland ice sheet. Therefore, we can exclude extensive deposition of carbonaceous particles in the accumulation zone as a cause for the dark region.

\section{RADIOCARBON DATING}

Because the amount of carbonaceous particles in most of the ice samples is very low, the measurement uncertainty becomes high and therefore the obtained ages cover relatively wide intervals. Table 4 presents an overview of the results, including the measurement errors. Owing to the low carbon concentrations, only a limited number of samples could be dated and therefore the results should be considered as first evidence.

The OC from the samples containing ice directly below the surface is modern. This is in agreement with the presence of microorganisms near the ice surface, as discussed in the previous section. The EC from S8-1 seems to be slightly older than the modern ages of the OC fraction. As it is likely that this material also originated from the surface, this might be due to the inbuilt age of the radiocarbon age of the EC (Gavin, 2001) or partly because the measurement error is larger. The ages of the OC and EC of S8-2, a sample at some depth below the surface, indicate that this sample is not modern. This confirms our hypothesis that old material is outcropping in this area. The EC appears to be younger than the OC for S8-2, contrary to the common idea that EC is either the same age as OC or is older due to the inbuilt age (e.g. Sigl and others, 2009). Although the presence of peaty particles might influence the age of the OC, this effect should be limited because their amounts will be small and wind-blown material will originate from upper soil layers. As the calibrated periods for each fraction in this sample partly overlap, it is likely that both EC and OC have the same age within their uncertainties. This results in an age between 2000 and $660 \mathrm{BP}$, in the Late Holocene.

During the Holocene, eolian activity in the ice-free areas of West Greenland has been variable. Willemse and others (2003) reported that, in the Kangerlussuaq tundra, regional silts were deposited continuously since $4750 \mathrm{BP}$ and the bulk of eolian sands before $3400 \mathrm{BP}$ and after $550 \mathrm{BP}$, but they also found indications for extreme phases of eolian activity prior to $3500 \mathrm{BP}$, around 3250 and $2800 \mathrm{BP}$ and between 1600 and $520 \mathrm{BP}$. This last period of increased eolian activity coincides with the age we reconstructed for the glacially transported material in sample S8-2 (2000-660 BP). Eisner and others (1995) investigated a sediment record from a lake in the Kangerlussuaq region and reported continuous eolian sand and silt depositions since $5000 \mathrm{BP}$, with a significant increase since $\sim 1000{ }^{14} \mathrm{C} \mathrm{BP}$ (provided without error). This increase is likely due to a higher sediment supply caused by a larger ice-free area. Note that the ${ }^{14} \mathrm{C}$ ages of the OC and EC in our sample S8-2 are $1720 \pm 560 \mathrm{BP}$ and $970 \pm 530 \mathrm{BP}$, respectively, which coincides with the period presented by Eisner and others (1995). Although not proven, we assume that in periods when the regional situation and climate conditions allow high eolian activity in the tundra, higher fluxes of eolian dust reach the ice sheet.

The OC from the reference sample S1-1 is older than the outcropping material from Site 8 . This is to be expected as Site 1 is located closer to the margin and the ice at this site is therefore older. However, in the previous section we concluded that organic material in this sample was likely picked up from the bedrock. In that case, not only glacially transported material from the accumulation zone, but also basally entrained organic debris has been dated. The age observed for this sample agrees well with the period when the bedrock was exposed and vegetation could have grown there. For example, Van Tatenhove and others (1996) reported circumstantial evidence that the ice-sheet margin retreated tens of kilometres behind its present position during the Holocene climatic optimum in this area. Weidick and others (1990) state that the tundra near Jakobshavn Isbræ was more ice-free than at present, at least in the period $2700-4700 \mathrm{BP}$. As our samples are from an area close to 
Table 4. Radiocarbon ages of carbonaceous particles from West Greenland. Absolute uncertainties indicate the $1 \sigma$ range. Calibrated ages are given within the $2 \sigma$ range. Calibrated ages are defined as modern where they are younger than AD 1950

\begin{tabular}{|c|c|c|c|c|c|c|}
\hline Sample & AMS label & $\begin{array}{c}\text { Mass } \\
\mu \mathrm{g}\end{array}$ & $f_{\mathrm{M}}$ & $f_{\mathrm{M} \text { correct }}$ & $\begin{array}{c}{ }^{14} \mathrm{C} \text { age } \\
\mathrm{BP}^{*}\end{array}$ & $\begin{array}{l}\text { Calibrated age } \\
\qquad \text { BP* }^{*}\end{array}$ \\
\hline S8-1 OC ${ }^{\dagger}$ & EG0901 & $131.5 \pm 2.9$ & $1.084 \pm 0.015$ & $1.089 \pm 0.016$ & $-690 \pm 120$ & Modern $(\leq-2)^{*}$ \\
\hline $\mathrm{S} 8-1 \mathrm{EC}^{\dagger}$ & EG0905 & $7.3 \pm 0.2$ & $0.964 \pm 0.037$ & $0.993 \pm 0.042$ & $60 \pm 340$ & $\leq 666^{\bar{\S}}$ \\
\hline S8-2 OC & EG0906 & $6.3 \pm 0.2$ & $0.767 \pm 0.028$ & $0.808 \pm 0.056$ & $1720 \pm 560$ & $30 \overline{7} 1-657^{\S}$ \\
\hline S8-2 EC & EG0908 & $4.9 \pm 0.2$ & $0.850 \pm 0.050$ & $0.886 \pm 0.058$ & $970 \pm 530$ & $\begin{array}{l}2001 \text { to modern } \\
(2001 \text { to }-5)^{\S}\end{array}$ \\
\hline $\mathrm{S} 8-3 \mathrm{OC}^{\dagger}$ & 40426 & $102.6 \pm 2.3$ & $1.071 \pm 0.008$ & $1.078 \pm 0.009$ & $-600 \pm 70$ & Modern $(0 \text { to }-48)^{3}$ \\
\hline $\mathrm{S} 7-1 \mathrm{OC}^{\dagger}$ & EG0902 & $115.7 \pm 2.6$ & $1.065 \pm 0.014$ & $1.070 \pm 0.016$ & $-540 \pm 12$ & Modern $(\leq 0)^{*}$ \\
\hline $\mathrm{S} 1-1 \mathrm{OC}$ & EG0903 & $32.3 \pm 0.7$ & $0.676 \pm 0.021$ & $0.678 \pm 0.023$ & $3120 \pm 270$ & $4080-2741^{\S}$ \\
\hline
\end{tabular}

${ }^{*} \mathrm{BP}$ : before AD 1950. ${ }^{\dagger}$ Samples containing ice from directly below the surface. ${ }^{\star}$ Calibrated with Bomb04 NH1 (Hua and Barbetti, 2004$) .{ }^{\S}$ Calibrated with IntCal09 (Reimer and others, 2009).

this region, it is likely that these conclusions also hold for our sampling sites. The age for our Site 1 sample, 2741$4080 \mathrm{BP}$, agrees well with these findings.

In summary, we can distinguish between modern carbon introduced by melting from the surface ice in the upper parts of our cores and older glacially transported material in samples taken at some depth. The observed radiocarbon age for probably vegetated bedrock material agrees well with the period of exposed tundra for this site. In addition, the radiocarbon ages for the outcropping material agree well with findings in the literature for high eolian activity. Therefore, we may conclude that the radiocarbon ages confirm our assumption of a Holocene age for the original deposition of the outcropping material in the dark region, during periods when higher amounts of local dust were available.

\section{CONCLUSIONS}

Although we have a limited number of samples, and carbon concentrations in the outcropping ice are lower than expected, we can draw some important conclusions. Samples of ice from directly below the surface show high concentrations of modern OC. This is probably caused by the presence of microbes on the ice surface. Modern material melted into the ice to an equilibrium depth, even though melt holes are not always visible. Ice beneath this equilibrium depth contains low concentrations of carbonaceous particles. These concentrations are independent of depth, indicating that the material is transported through the ice. This is confirmed by the only sample taken at some depth that could be dated, which revealed that the carbon in this sample is not modern and settled on the ice sheet during the Late Holocene.

The dust from our reference ice at Site 1, a site close to the margin, seems to contain basally entrained material. Therefore, the age of the OC (4080-2741 BP) does not represent the date of uptake by the ice, but the time of growth of vegetation on the bedrock. The bedrock was icefree at least during the period 4700-2700 BP (Weidick and others, 1990). The radiocarbon age of this sample coincides with this period when the bedrock was likely exposed and biological activity was possible.

The concentrations of glacially transported OC in our samples seem to be lower than for other Holocene samples from GRIP. It is not clear why this is the case, but different locations and therefore other sources, transport routes and deposition processes might be an explanation. Both OC and EC concentrations of the glacially transported material in our samples are slightly lower than concentrations for the Younger and Older Dryas in the nearby Paakitsoq area. This indicates that less organic material settled in the accumulation zone relative to glacial periods. The outcropping material in our samples reveals EC concentrations in the same order of magnitude as generally observed in ice cores from the Holocene age in Greenland. Hence, the dark region seems not to be caused by periods of high EC deposition on the ice sheet, such as by extensive forest fires or anthropogenic emissions, but rather by periods with high mineral dust fluxes. During periods in which higher amounts of eolian mineral dust from the tundra settled on the ice sheet, EC and OC fluxes, even if they are small, can be increased as well. This is confirmed by higher concentrations of carbonaceous particles in ice samples from the dark region relative to reference ice samples. In addition, the age for the outcropping carbon coincides with independent reported values (Eisner and others, 1995; Willemse and others, 2003) for a likely increased eolian activity in the nearby tundra. This completes the findings of Wientjes and others (2011), who revealed that surface dust in the dark region consists mainly of minerals and microbes and who presented strong indications that the dust causing the dark region has a local source, based on geochemical analyses.

Measurements of absolute concentrations of outcropping mineral dust in the ice could confirm their higher amounts in the dark region. As we only succeeded in dating one sample with outcropping material, more radiocarbon measurements with larger samples to obtain higher amounts of carbon are required to find out more about the exact period when the dust settled on the ice sheet. Differences in dust fluxes during the Holocene induced by variable local conditions seem to contribute to outcropping dust layers and therefore to albedo variations observed in the ablation zone at present, which affect present-day melt rates.

\section{ACKNOWLEDGEMENTS}

We thank P. Smeets, H. Snellen and C. van der Veen for assistance with fieldwork and transportation of material. We thank Manuel Schläppi for help with ice sample preparation. We thank two anonymous reviewers for valuable comments 
which helped to improve the paper. Financial support for this work is provided through the Spinoza grant and the KNAW Professorship of J. Oerlemans.

\section{REFERENCES}

Bronk Ramsey C (2001) Development of the radiocarbon calibration program. Radiocarbon, 43(2A), 355-363

Chylek $\mathrm{P}$ and 7 others (1987) Aerosol and graphitic carbon content of snow. J. Geophys. Res., 92(D8), 9801-9809 (doi: 10.1029/ JD092iD08p09801)

Chylek P, Johnson B and Wu H (1992) Black carbon concentration in a Greenland Dye-3 ice core. Geophys. Res. Lett., 19(19), 1951-1953 (doi: 10.1029/92GL01904)

Chylek P, Johnson B, Damiano P, Taylor KC and Clement P (1995) Biomass burning record and black carbon in the GISP2 ice core. Geophys. Res. Lett., 22(2), 89-92 (doi: 10.1029/94GL02841)

Clarke AD and Noone KJ (1985) Soot in the Arctic snowpack: a cause for perturbations in radiative transfer. Atmos. Environ., 19(12), 2045-2053

Eisner WR, Törnqvist TE, Koster EA, Bennike $\mathrm{O}$ and Van Leeuwen JFN (1995) Paleoecological studies of a Holocene lacustrine record from the Kangerlussuaq (Søndre Strømfjord) region of west Greenland. Quat. Res., 43(1), 55-66

Gavin DG (2001) Estimation of inbuilt age in radiocarbon ages of soil charcoal for fire history studies. Radiocarbon, 43(1), 27-44

Greuell W (2000) Meltwater accumulation on the surface of the Greenland ice sheet: effect on albedo and mass balance. Geogr. Ann., Ser. A, 82(4), 489-498

Gribbon PWF (1979) Cryoconite holes on Sermikavsak, West Greenland. J. Glaciol., 22(86), 177-181

Hagler GSW, Bergin MH, Smith EA, Dibb JE, Anderson C and Steig EJ (2007) Particulate and water-soluble carbon measured in recent snow at Summit, Greenland. Geophys. Res. Lett., 34(16), L16505 (doi: 10.1029/2007GL030110)

Hua $Q$ and Barbetti M (2004) Review of tropospheric bomb ${ }^{14} \mathrm{C}$ data for carbon cycle modeling and age calibration purposes. Radiocarbon, 46(3), 1273-1298

Jenk TM (2006) Ice core based reconstruction of past climate conditions and air pollution in the Alps using radiocarbon. (PhD thesis, University of Bern)

Jenk TM and 7 others (2006) Radiocarbon analysis in an Alpine ice core: record of anthropogenic and biogenic contributions to carbonaceous aerosols in the past (1650-1940). Atmos. Chem. Phys., 6(12), 5381-5390 (doi: 10.5194/acp-6-538-2006)

Jenk TM and 6 others (2007) Microgram level radiocarbon $\left({ }^{14} \mathrm{C}\right)$ determination on carbonaceous particles in ice. Nucl. Instrum. Meth. Phys. Res. B, 259(1), 518-525 (doi: 10.1016/j. nimb.2007.01.196)

Jenk TM and 9 others (2009) A novel radiocarbon dating technique applied to an ice core from the Alps indicating late Pleistocene ages. J. Geophys. Res., 114(D14), D14305 (doi: 10.1029/ 2009JD011860)

Knap WH and Oerlemans J (1996) The surface albedo of the Greenland ice sheet: satellite-derived and in situ measurements in the Søndre Strømfjord area during the 1991 melt season. J. Glaciol., 42(141), 364-374

McConnell JR and 9 others (2007) 20th-century industrial black carbon emissions altered Arctic climate forcing. Science, 317(5843), 1381-1384 (doi: 10.1126/science.1144856)
Oerlemans J and Vugts HF (1993) A meteorological experiment in the melting zone of the Greenland ice sheet. Bull. Am. Meteorol. Soc., 74(3), 355-365

Petrenko VV, Severinghaus JP, Brook EJ, Reeh N and Schaefer H (2006) Gas records from the West Greenland ice margin covering the Last Glacial Termination: a horizontal ice core. Quat. Sci. Rev., 25(9-10), 865-875 (doi: 10.1016/j.quascirev.2005.09.005)

Reeh N, Thomsen HH and Clausen HB (1987) The Greenland icesheet margin - a mine of ice for paleo-environmental studies. Palaeogeogr., Palaeoclimatol., Palaeoecol., 58(3-4), 229-234 (doi: 10.1016/0031-0182(87)90062-9)

Reeh N, Oerter $\mathrm{H}$ and Thomsen $\mathrm{HH}$ (2002) Comparison between Greenland ice-margin and ice-core oxygen-18 records. Ann. Glaciol., 35, 136-144 (doi: 10.3189/172756402781817365)

Reimer PJ and 27 others (2009) IntCal09 and Marine09 radiocarbon age calibration curves, 0-50,000 years cal BP. Radiocarbon, 51(4), 1111-1150

Ruff M, Wacker L, Gäggeler HW, Suter M, Synal H-A and Szidat S (2007) A gas ion source for radiocarbon measurements at 200 kV. Radiocarbon, 49(2), 307-314

Sigl $M$ and 9 others (2009) Towards radiocarbon dating of ice cores. J. Glaciol., 55(194), 985-996 (doi: 10.3189/ 002214309790794922)

Slater JF, Currie LA, Dibb JE and Benner BA Jr (2002) Distinguishing the relative contribution of fossil fuel and biomass combustion aerosols deposited at Summit, Greenland, through isotopic and molecular characterization of insoluble carbon. Atmos. Environ., 36(28), 4463-4477 (doi: 10.1016/S1352-2310(02)00402-8)

Stibal M, Lis GP, Lawson E, Mak KM, Wadham JL and Anesio AM (2010) Organic matter content and quality in supraglacial debris across the ablation zone of the Greenland ice sheet. Ann. Glaciol., 51(56), 1-8 (doi: 10.3189/172756411795931958)

Synal H-A, Stocker M and Suter M (2007) MICADAS: a new compact radiocarbon AMS system. Nucl. Instrum. Meth. Phys. Res. B, 259(1), 7-13 (doi: 10.1016/j.nimb.2007.01.138)

Szidat S and 6 others (2004) THEODORE, a two-step heating system for the EC/OC determination of radiocarbon $\left({ }^{14} \mathrm{C}\right)$ in the environment. Nucl. Instrum. Meth. Phys. Res. B, 223-224 829-836 (doi: 10.1016/j.nimb.2004.04.153)

Van de Wal RSW and Oerlemans J (1994) An energy balance model for the Greenland ice sheet. Global Planet. Change, 9(1-2), 115-131

Van Tatenhove FGM, Van der Meer JJM and Koster EA (1996) Implications for deglaciation chronology from new AMS age determinations in central West Greenland. Quat. Res., 45(3), 245-253 (doi: 10.1006/qres.1996.0025)

Weidick A, Oerter H, Reeh N, Thomsen HH and Thoring L (1990) The recession of inland ice margin during the Holocene climatic optimum on the Jacobshavn Isfjord area of west Greenland. Palaeogeogr., Palaeoclimatol., Palaeoecol., 82(3-4), 389-399

Wientjes IGM and Oerlemans J (2010) An explanation for the dark region in the western melt zone of the Greenland ice sheet. Cryosphere, 4(3), 261-268 (doi: 10.5194/tc-4-261-2010)

Wientjes IGM, Van de Wal RSW, Reichart GJ, Sluijs A and Oerlemans J (2011) Dust from the dark region in the western ablation zone of the Greenland ice sheet. Cryosphere, 5(3), 589-601 (doi: 10.5194/tc-5-589-2011)

Willemse NW, Koster EA, Hoogakker B and Van Tatenhove FGM (2003) A continuous record of Holocene eolian activity in West Greenland. Quat. Res., 59(3), 322-334 (doi: 10.1016/S00335894(03)00037-1) 